\title{
Synthesis and Characterization of ZnO-decorated GO Nanocomposite Material with Different ZnO Loading through Sol-gel Method
}

(Penghasilan dan Perincian Komposit Nano GO-ZnO dengan Muatan ZnO yang Berbeza melalui Kaedah Sol-gel)

\author{
Nurul 'Adilah Rosnan \\ Chemical Engineering Program, \\ Faculty of Engineering \& Built Environment, Universiti Kebangsaan Malaysia, Bangi, Malaysia \\ Teow Yeit Haan* \\ Research Centre for Sustainable Process Technology (CESPRO), \\ Faculty of Engineering \& Built Environment, Universiti Kebangsaan Malaysia, Bangi, Malaysia \\ Abdul Wahab Mohammad \\ Qatar Energy and Environment Research Institute (QEERI), Hamad bin Khalifa University (HBKU), Qatar Foundation, Doha, Qatar
}

\begin{abstract}
This work aimed is to synthesis a well dispersed zinc oxide ( $\mathrm{ZnO})$ nanoparticles (NPs) decorated on graphene oxide (GO) nanosheet with a practical way by using sol-gel technique. Zinc acetate dehydrate $\left(\mathrm{Zn}\left(\mathrm{CH}_{3} \mathrm{COO}\right)_{2} \cdot 2 \mathrm{H}_{2} \mathrm{O}\right)$ was used as precursor of $\mathrm{ZnO}$ and absolute ethanol as solvent. 1 weight percent (wt\%), $5 \mathrm{wt} \%, 10 \mathrm{wt} \%$, and $20 \mathrm{wt} \%$ of ZnO was decorated on GO nanosheet. A series of analysis was carried out to characterize the synthesized ZnO-decorated GO nanocomposite material. The results of XRD analysis show some long area of peak at $25^{\circ}$ to $80^{\circ}$ allocate for $\mathrm{ZnO}$ in the $\mathrm{ZnO}$-decorated GO nanocomposite material. By performing zeta potential analysis, the findings show that there was increment of negative surface charge on ZnO-decorated GO nanocomposite material. The experiment result also found that the hydrodynamic particle size of ZnO-decorated GO nanocomposite material become larger when high ZnO loaded. FESEM micrographs demonstrated that spherical-shaped of ZnO NPs appeared on the GO nanosheet with further proved by EDX where the content of ZnO-decorated GO nanocomposite material was composed by $71.3 \mathrm{wt} \%$ of C, $17 \mathrm{wt} \%$ of O, and additional element of $11.7 \mathrm{wt} \%$ of $\mathrm{Zn}$. Thus, it can summarize that the synthesized $\mathrm{ZnO}$-decorated GO nanocomposite material was high in purity. The findings in this study proved that $\mathrm{ZnO}$ NPs loading in ZnO-decorated GO nanocomposite material were successfully synthesized by sol-gel method. A ZnO-decorated GO nanocomposite material with layering ZnO NPs on GO nanosheet was produced.
\end{abstract}

Keywords: Sol-gel; Zinc oxide; Graphene oxide; Nanoparticles

ABSTRAK

Kajian ini bertujuan untuk sintesis serakan zink oksida (ZnO) zarah nano (NPS) yang baik pada permukaan kepingan nano grafin oksida (GO) dengan cara praktikal iaitu melalui kaedah sol-gel. Zink asetat diyahhidratkan $\left.\left(\mathrm{Zn}_{(\mathrm{CH}} \mathrm{CH}_{3} \mathrm{COO}\right)_{2} \cdot 2 \mathrm{H}_{2} \mathrm{O}\right)$ digunakan sebagai pelopor $\mathrm{ZnO}$ dan etanol mutlak sebagai pelarut. Sebanyak 1 berat peratus (wt\%), $5 w t \%, 10 w t \%$, dan $20 \mathrm{wt} \% \mathrm{ZnO}$ dimuatkan ke atas kepingan nano GO. Beberapa analisis telah dilaksanakan untuk mencirikan komposit nano GO-ZnO yang dihasilkan. Keputusan XRD mempamerkan beberapa puncak luas dalam lingkungan $25^{\circ}$ hingga $80^{\circ}$ di mana ia menunjukkan kepada ZnO dalam komposit nano GO-ZnO. Dengan melakukan analisis potensi zeta, keputusan menunjukkan bahawa terdapat peningkatan caj permukaan negatif pada komposit nano GO-ZnO. Keputusan uji kaji juga mendapati bahawa saiz zarah hidrodinamik komposit nano GO-ZnO menjadi besar apabila banyak ZnO dimuatkan. FESEM mikrograf menunjukkan bahawa ZnO NPS berbentuk sfera muncul pada permukaan kepingan nano GO dibuktikan selanjutnya oleh EDX di mana kandungan komposit nano GO-ZnO terdiri daripada $71.3 \%$ berat $C, 17 \%$ berat $O$, dan elemen tambahan $11.7 \%$ berat Zn. Oleh itu, dapat disimpulkan bahawa komposit nano GO-ZnO yang disintesis adalah tinggi ketulenannya. Penemuan yang terdapat dalam kajian ini membuktikan bahawa pemuatan ZnO NPs pada komposit nano GO-ZnO berjaya disintesis oleh kaedah sol-gel. Komposit nano GO-ZnO dengan salutan seragam dan ikatan yang kuat antara ZnO NPs dan permukaan kepingan nano GO telah dihasilkan.

Kata kunci: Sol-gel; Zink oksida; Grafin oksida; Zarah nano 


\section{INTRODUCTION}

There are $\mathrm{ZnO}$ NPs has emerged as one of the highly promising metal NPs used in many applications, including gas sensor, protective coatings, electro photography, solar cells (Hasnidawani et al. 2016), healthcare, optics, ultraviolet, and blue light emitting diodes, and in the evolution of membrane area, due to their excellent properties of antimicrobial, anticorrosive, thermal, and mechanical stability (Fan \& Lu 2005; Vaseem et al. 2010; Wang et al. 2002), high catalytic activity, strong adsorption capacity, low toxicity, and environmental friendly feature (Vaseem et al. 2010).

In membrane technology area, incorporation of $\mathrm{ZnO}$ NPs into polymer matrix has proven could improve the implementation of membrane such as water flux, rejection capability, and antifouling property (Liang et al. 2012; Shen et al. 2012; Zhao et al. 2015). These positive improvements attributed by $\mathrm{ZnO}$ NPs make it an excellent NPs filler for the improvement of membrane quality and lead to high efficiency of protein concentrated and fractionated without change the properties of food components.

However, high surface energy of $\mathrm{ZnO}$ NPs often resulted an agglomeration in membrane matrix, leading to low functional surface area and apparently gives drawback for its applications (Amat et al. 2012). GO nanosheet have recently introduced as a reliable platform for better nanomaterial dispersion (Bao et al. 2011). GO formed from oxidation of graphite were fascinating carbon material that carried hydroxyl and epoxies functional groups on their basal planes, in addition carbonyl and carboxyl groups located at the sheet edges (Qin et al. 2014). These functional groups of GO nanosheet are essential in forming hybrid nanostructures with various kinds of NPs such as silver $(\mathrm{Ag})$, silicon dioxide $\left(\mathrm{SiO}_{2}\right)$, and titanium dioxide $\left(\mathrm{TiO}_{2}\right)(\mathrm{Ng}$ et al. 2013).

These functional groups makes GO nanosheet become more hydrophilic, enable the GO to readily exfoliate in water to yield stable dispersion (Paredes et al. 2008). The synergistic effects between the hydrophilic-layered GO nanosheet and NPs make it adaptable. By having these interactions, the combination of both $\mathrm{ZnO}$ and $\mathrm{GO}$ would form nanohybrids with special properties. Recently, many researchers have explored the synthesize of $\mathrm{ZnO}$-decorated GO nanocomposite material and it exhibit potential application in photocatalysis and supercapacitor (Gayathri et al. 2014; Li et al. 2012). In addition, Chen et al. (2013) had successfully proved that $\mathrm{ZnO}$-decorated GO nanocomposite material has been shown to have better photo catalytic activity.

Researchers have developed variety of technique to synthesize these nanomaterials. The principle methods that have been put forward in the literature to synthesize these materials, namely spray pyrolysis, hydrothermal, chemical vapor condensation, precipitation, sol-gel method (Tavakoli et al. 2007; Van Werde et al. 2002), electrochemical method, and electrochemical depositions (Chu \& Li 2012; Stypuła et al. 2014). The crystallite size and morphology of nanomaterials strongly depend on synthesis method. It is particularly interesting to synthesize $\mathrm{ZnO}$ by the sol-gel process because of its simplicity, reproducibility, low cost of the chemicals (Luković Golić et al. 2011), and sol-gel chemistry is effective for controlling morphology and reactivity of solids (Benhebal et al. 2013). Instead, in recent years it has shown improvement for dispersing materials, promoting good homogeneity and purity (Bodson et al. 2010; Lambert et al. 2004).

Herein, we synthesize the $\mathrm{ZnO}$-decorated GO nanocomposite material using sol-gel method. A uniformly distributed of $\mathrm{ZnO}$ NPs onto GO nanosheet to produce $\mathrm{ZnO}$ decorated GO nanocomposite material was investigated. In this work, the effects of varying the $\mathrm{ZnO}$ loadings onto $\mathrm{ZnO}$ decorated GO nanocomposite material were characterized and reported in this study for better understanding the properties of nanohybrid material.

\section{METHODOLOGY}

MATERIALS

Graphite powder (particle size $<50 \mu \mathrm{m}$ ), zinc acetate dehydrates $\left(\mathrm{Zn}\left(\mathrm{CH}_{3} \mathrm{COO}\right)_{2} \cdot 2 \mathrm{H}_{2} \mathrm{O}\right)$, oxalic acid $\left(\mathrm{C}_{2} \mathrm{H}_{2} \mathrm{O}_{4} \cdot 2 \mathrm{H}_{2} \mathrm{O}\right)$, and sodium nitrate $\left(\mathrm{NaNO}_{3}\right)$ were bought from Merck Co., Germany. $98 \%$ sulfuric acid $\left(\mathrm{H}_{2} \mathrm{SO}_{4}\right), 38 \%$ hydrochloric acid ( $\mathrm{HCl}$ ), 30\% hydrogen peroxide $\left(\mathrm{H}_{2} \mathrm{O}_{2}\right)$, absolute ethanol, and potassium permanganate $\left(\mathrm{KMnO}_{4}\right)$ were bought from Sigma Aldrich, USA. Analytical grade of chemicals was used.

SYNTHESIS OF GO

Following the modify Hummers method, graphite powder was chemically oxidized at low temperature, resulting a brown colloidal suspension known as GO (Hummers JR \& Offeman 1958). Typically, $5 \mathrm{~g}$ of graphite powder and 2.5 $\mathrm{g}$ of $\mathrm{NaNO}_{3}$ were added into $115 \mathrm{~mL}$ of $98 \% \mathrm{H}_{2} \mathrm{SO}_{4}$ and stirred at $300 \mathrm{rpm}$ for $1 \mathrm{~h}$ under room temperature. The mixture was further stirred for $30 \mathrm{~min}$ in ice bath until it hit $10^{\circ} \mathrm{C}$ before $\mathrm{KMnO}_{4}$ was gradually added under continuous stirring. The mixture was left $\mathrm{t}$ for $2 \mathrm{~h}$ while keeping the temperature less than $10^{\circ} \mathrm{C}$. It was then stirred at $35^{\circ} \mathrm{C}$ for another $1 \mathrm{~h}$. Following, $230 \mathrm{~mL}$ deionized water was added to dilute the mixture and stirred at temperature below $100^{\circ} \mathrm{C}$. Further dilution was done with $300 \mathrm{~mL}$ deionized water and stirred for another $1 \mathrm{~h}$ to remove metal ion. The reaction was terminated by adding $10 \mathrm{~mL}$ of $30 \% \mathrm{H}_{2} \mathrm{O}_{2}$ into the mixture. The dispersion was washed, rinsed with $5 \% \mathrm{HCl}$ aqueous solution, followed by second rinse with deionized water. The final fine brown powder product was freeze dried under vacuum at $-40^{\circ} \mathrm{C}$ for further study.

\section{SYNTHESIS OF ZNO-DECORATED GO NANOCOMPOSITE MATERIAL}

Initially, $0.3 \mathrm{~g}$ of $\mathrm{GO}$ was dispersed in $10 \mathrm{~mL}$ of absolute ethanol via sonication to produce GO suspension. Then, $\mathrm{Zn}\left(\mathrm{CH}_{3} \mathrm{COO}\right)_{2} \cdot 2 \mathrm{H}_{2} \mathrm{O}$ mixed into $90 \mathrm{~mL}$ of absolute ethanol under vigorous stirring at $65^{\circ} \mathrm{C}$ for $30 \mathrm{~min}$. Next, $\mathrm{Zn}\left(\mathrm{CH}_{3} \mathrm{COO}\right)_{2} \cdot 2 \mathrm{H}_{2} \mathrm{O} /$ absolute ethanol mixture was added slowly into GO suspension with stirred for $20 \mathrm{~min}$ at $45^{\circ} \mathrm{C}$. 
Later, $1 \mathrm{~g}$ of $\mathrm{C}_{2} \mathrm{H}_{2} \mathrm{O}_{4} \cdot 2 \mathrm{H}_{2} \mathrm{O}$ dissolved in $50 \mathrm{~mL}$ absolute alcohol was poured into the mixture solution and let it stir for another $1 \mathrm{~h}$ and $30 \mathrm{~min}$. Collect the precipitate by centrifugation and dried at $65^{\circ} \mathrm{C}$ overnight in an oven, followed by calcination at $400^{\circ} \mathrm{C}$ for $3 \mathrm{~h}$ to get final product. $\mathrm{ZnO}$-decorated $\mathrm{GO}$ nanocomposite material with different weight percent of $\mathrm{ZnO}$ NPs (1\%, 5\%, 10\%, and 20\%) were earned by manipulating the ration of $\mathrm{Zn}\left(\mathrm{CH}_{3} \mathrm{COO}\right)_{2} \cdot 2 \mathrm{H}_{2} \mathrm{O}$ in the synthesis process.

\section{SYNTHESIS OF ZNO-DECORATED GO NANOCOMPOSITE MATERIAL}

X-RAY DIFFRACTION (XRD)

The crystal phase composition of synthesized ZnO-decorated GO nanocomposite material was interpret using D8 Advance X-ray diffractometer (Bruker AXs, Germany) with $\mathrm{CuK \alpha}$ radiation source $(1.5406 \AA)$ at $2 \theta$ scan range of $5^{\circ}$ to $85^{\circ}$. The average crystallite size (D) of the nanomaterial was calculated from its XRD pattern based on Scherrer's equation.

$$
\mathrm{D}=\frac{k \lambda}{\beta \cos \theta}
$$

Where $\mathrm{k}$ is the Scherrer constant (0.89), is the X-ray wavelength $(0.1540 \mathrm{~nm}), \beta$ is the peak width at half maximum $\left.{ }^{\circ}\right)$, and $\theta$ is the Bragg diffraction angle $\left(^{\circ}\right)$.

FOURIER TRANSFORM INFRARED SPECTROSCOPY (FTIR)

Nicolet 6700 FTIR spectrometer (Thermo Fisher Scientific Inc., USA) recorded the FTIR spectrum coupled with a diamond crystal at incidence angle at $45^{\circ}$ to point out possible functional groups of GO nanosheet. 32 scans with $4 \mathrm{~cm}^{-1}$ resolutions to obtained and spectrum and has operated at wavelength from $4000 \mathrm{~cm}^{-1}$ to $500 \mathrm{~cm}^{-1}$.

FIELD EMISSION SCANNING ELECTRON MICROSCOPY (FESEM) AND ENERGY DISPERSIVE X-RAY SPECTROSCOPY (EDX)

High resolution FESEM Gemini model SUPRA 55VP (Calr Zeiss, Germany) was used to investigate the morphology and distribution of the GO nanosheet and ZnO NPs. All nanomaterials were covered with a thin layer of platinum under vacuum to reduce the charge on the surface so that contrastive images formed. FESEM imaging was observed at the magnification of $100 \mathrm{k}$ for finding out the shape of $\mathrm{ZnO}$ NPs deposition on GO. In a meantime, the element composition of the same sample was analyzed using EDX, Oxford INCA PentaFETX3 (Oxford, UK).

HYDRODYNAMIC PARTICLE SIZE AND ZETA POTENTIAL

The zeta potential and hydrodynamic particle size of the synthesized ZnO-decorated GO nanocomposite material were examined using ZetaSizer Nano-ZS (Malvern instruments Inc., UK) which works on the principle of dynamic light scattering (DLS) where it measures the intensity of the laser light scattered from suspended particles. Prior hydrodynamic particle size and zeta potential measurement, $\mathrm{ZnO}$-decorated GO nanocomposite material was dispersed in water at the concentration of $0.1 \mathrm{w} / \mathrm{v} \%$ (weight of $\mathrm{ZnO}$-decorated GO nanocomposite material/volume of water, solvent), and sonicated using a bath sonicator for $30 \mathrm{~min}$ to ensure a uniform suspension.

\section{RESULTS AND DISCUSSIONS}

\section{CHARACTERIZATION OF GO AND ZNO-DECORATED GO NANOCOMPOSITE MATERIAL}

The XRD pattern of graphite, GO, and $20 \mathrm{wt} \%$ of $\mathrm{ZnO}$ loaded in $\mathrm{ZnO}$-decorated GO nanocomposite material are set out in Figure 1. Pristine graphite depicted a tenacious peak at $26.5^{\circ}$ and relocated to $10.8^{\circ}$, as graphite powder was chemically oxidized to form GO through modified Hummers method. Exfoliation of graphite into GO (Ahmed et al. 2016; Chao et al. 2008) disrupted the basal plane of graphite by adding carbonyl $(\mathrm{C}=\mathrm{O})$ and carboxyl $(\mathrm{C}-\mathrm{OOH})$ groups located at the edge of graphene nanosheet (Wang et al. 2014; Williams \& Kamat 2009).

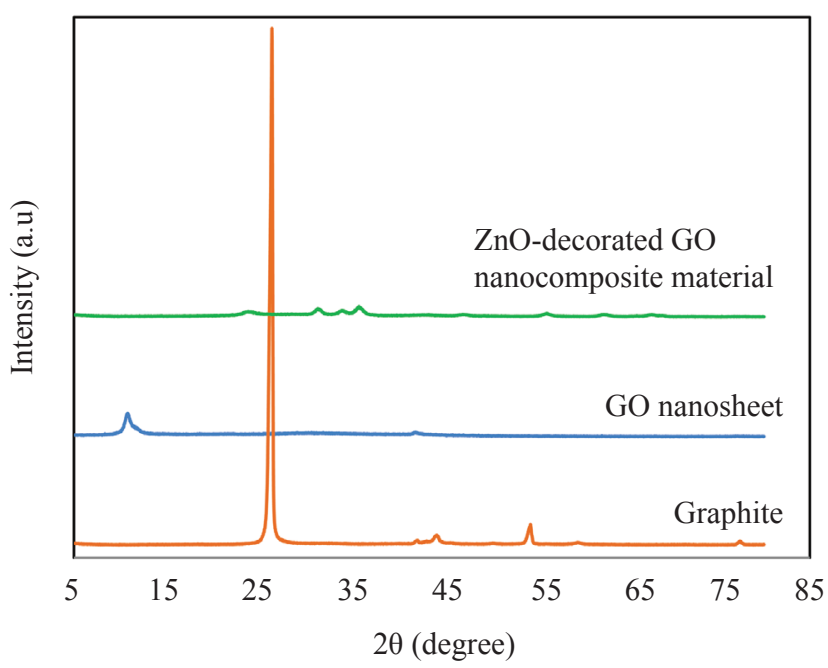

FIGURE 1. XRD pattern of graphite, GO, and $20 \mathrm{wt} \%$ of $\mathrm{ZnO}$ loaded in $\mathrm{ZnO}$-decorated GO nanocomposite material

Followed by decoration of ZnO NPs on GO nanosheet, the GO nanosheet peak at $10.8^{\circ}$ was gone. It was reported that the exfoliation of regular stacks of GO or graphite could diminish or even disappeared the diffraction peak (Chao et al. 2008). However, $\mathrm{ZnO}$-decorated GO nanocomposite material demonstrate some broad peaks in the range $25^{\circ}$ to $80^{\circ}$ which assigned by $\mathrm{ZnO}$ NPs decorated on GO nanosheet $(\mathrm{Xu}$ et al. 2014). The average crystallite size of $\mathrm{ZnO}$-decorated GO nanocomposite material was calculated from its XRD pattern based on Scherrer's equation. The calculated result showed that the average crystallite size of $\mathrm{ZnO}$-decorated GO nanomaterial was $9.92 \mathrm{~nm}$ which was in the range $5-20 \mathrm{~nm}$ as reported by Chung et al. (2017). 
The presence of functional groups on GO nanosheet was put forward by FTIR spectra as shown in Figure 2. Peak at $1627.40 \mathrm{~cm}^{-1}$ was pointed to $\mathrm{C}=\mathrm{O}$ stretching vibration whereas the broad peak around $3586.10 \mathrm{~cm}^{-1}$ resemble O-H stretching vibration (Chung et al. 2017). In addition, two bands at $1070.40 \mathrm{~cm}^{-1}$ and $1417.13 \mathrm{~cm}^{-1}$ are referred to by $\mathrm{C}-\mathrm{OOH}$ and alkoxy $(\mathrm{C}-\mathrm{O})$ groups, respectively. The presence of the aforementioned functional groups confirmed the successful of graphite oxidized to GO, coincident with other researchers (Anitha \& Jayakumari 2015; Kavitha et al. 2013). However, black color of $\mathrm{ZnO}$-decorated GO nanocomposite material limited the analysis using FTIR as poor infrared transmittance was produced due to the strong absorption characteristic from the dark color of sample. Therefore, ZnO-decorated GO nanocomposite material was characterized using FESEM and EDX analysis.

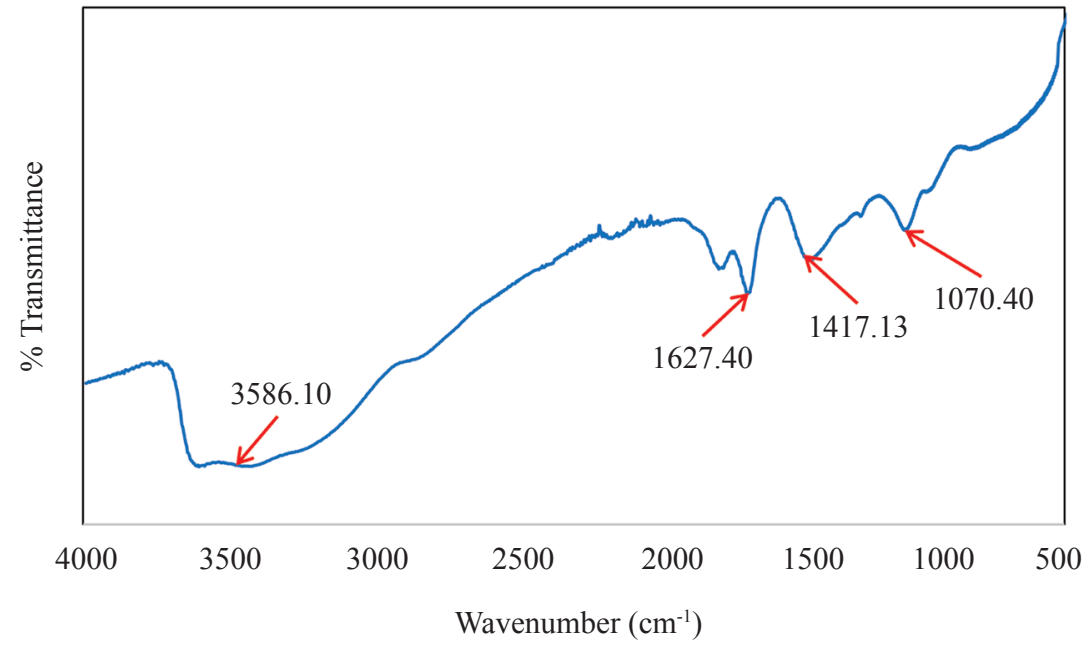

FIGURE 2. FTIR spectra of GO

The morphology and distribution of GO and ZnO NPs were characterized using FESEM, while the elemental compositions that has been existent on both nanomaterials were inspect using EDX. Figure 3(a) and Figure 3(b) showed the FESEM micrographs and EDX spectra of GO and $\mathrm{ZnO}$-decorated GO nanocomposite material, respectively. EDX analysis confirmed the deposition of ZnO NPs (white spots in FESEM micrograph) on $\mathrm{ZnO}$-decorated $\mathrm{GO}$ nanocomposite material. As depicted in Figure 3(b), the element compositions attributed by GO consist of carbon and oxygen. In which their weight percent were 65 $\mathrm{wt} \%$ and $35 \mathrm{wt} \%$ for carbon and oxygen, respectively. On the other hand, $\mathrm{ZnO}$-decorated $\mathrm{GO}$ nanocomposite material was having additional element, zinc ( $\mathrm{Zn}$ ) as compared to GO. The weight percent for carbon, $\mathrm{Zn}$, and oxygen element existed in $\mathrm{ZnO}$-decorated GO nanocomposite were $71 \mathrm{wt} \%, 11.7 \mathrm{wt} \%$, and $17 \mathrm{wt} \%$ respectively. The EDX analysis has confirmed the success deposition of $\mathrm{ZnO}$ NPs on GO in synthesizing $\mathrm{ZnO}-$ decorated GO nanocomposite material with high purity.

Table 1 showed the hydrodynamic particle size of $\mathrm{ZnO}$ decorated GO nanocomposite material with different weight percent of $\mathrm{ZnO}$ loading. The hydrodynamic particle size was first decreased with the increasing of $\mathrm{ZnO}$ loading up to $5 \%$. Larger hydrodynamic particle size at $1 \mathrm{wt} \%$ of $\mathrm{ZnO}$ loading was noted from the result may be attributed to the rapid combination of reagents during particles synthesized as reported by (Duffy et al. 2007). Zhang et al. (2009) reported that appropriate amount of mixture between precursor and solvent causing higher viscosity and faster increase in evaporative gelation of solution will complete the solutiongel transition in a short time and prevent aggregation. Thus, other reason of larger hydrodynamic particle size at $1 \mathrm{wt} \%$ of
$\mathrm{ZnO}$ loading may due to the amount of $\mathrm{Zn}\left(\mathrm{CH}_{3} \mathrm{COO}\right)_{2} \cdot 2 \mathrm{H}_{2} \mathrm{O}$ was not appropriate with oxalic acid causing agglomeration occurred.

The hydrodynamic particle size was increased as the weight percent of $\mathrm{ZnO}$ was loaded further at higher amount. When the weight percent of $\mathrm{ZnO}$ was increased, it leads to the increase higher viscosity, where an increase in hydrodynamic particle size is expected. Since the frequency of particle collision is a strong function of particle concentration (Marsalek 2014; Friedlander 2000), ZnO-decorated GO nanocomposite material at high $\mathrm{ZnO}$ loading has high risk to collide, and agglomerate in suspension, hence resulted an increase in hydrodynamic particle size (Domingos et al. 2009; Suttiponparnit et al. 2011).

Figure 4 showed the zeta potential of $\mathrm{ZnO}$-decorated GO nanocomposite material with different $\mathrm{ZnO}$ loading. Zeta potential is denoted for surface charge of the particle (Mandzy et al. 2005). In general, zeta potential below -30 $\mathrm{mV}$ or beyond $+30 \mathrm{mV}$ considered as the criterion for a

TABLE 1. Hydrodynamic particle size of ZnO-decorated GO nanocomposite material with different $\mathrm{ZnO}$ loaded onto GO nanosheet

\begin{tabular}{cc}
\hline $\begin{array}{c}\text { ZnO loaded onto GO nanosheet } \\
(\mathrm{wt} \%)\end{array}$ & $\begin{array}{c}\text { Hydrodynamic particle size } \\
(\mathrm{nm})\end{array}$ \\
\hline 1 & 56.91 \\
5 & 28.35 \\
10 & 38.33 \\
20 & 42.59 \\
\hline
\end{tabular}



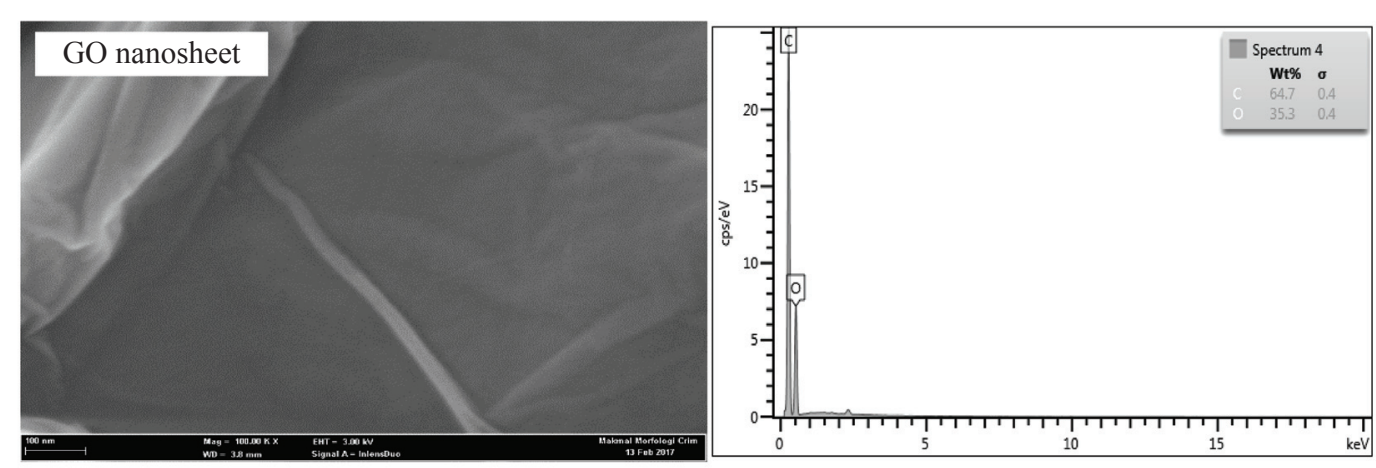

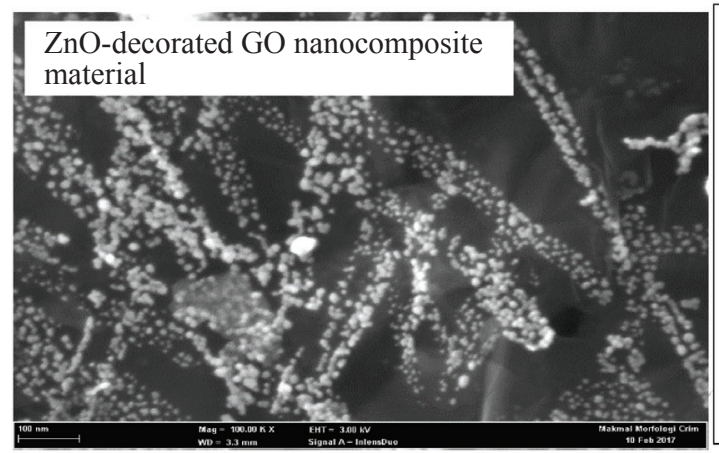

(a)

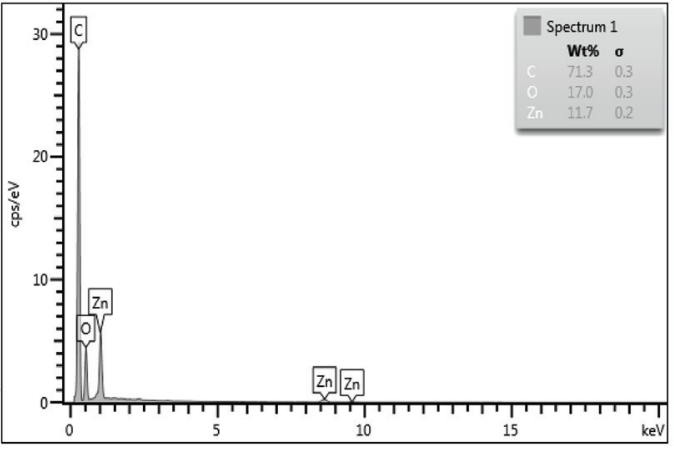

(b)

FIGURE 3. (a) FESEM micrographs and (b) EDX spectra of GO nanosheet and ZnO-decorated GO nanocomposite material loaded with $20 \mathrm{wt} \%$ of $\mathrm{ZnO} \mathrm{NPS}$

stable dispersion, high electrostatic repulsion is expected to manage the particles in suspension to repel each other (Ho et al. 2017; Zhang et al. 2013).

As depicted by Figure 4, $\mathrm{ZnO}$-decorated GO nanocomposite material with desired $\mathrm{ZnO}$ loading were having zeta potential value of $-17.4 \mathrm{mV},-16.90 \mathrm{mV},-20.30$ $\mathrm{mV}$, and $-28.23 \mathrm{mV}$, respectively, suggesting $\mathrm{ZnO}$-decorated GO nanocomposite material was approaching stability to produce uniform NPs distribution at higher $\mathrm{ZnO}$ loading, which expected a uniform nanomaterials distribution when incorporation with variety applications for enhancing the process efficiency.

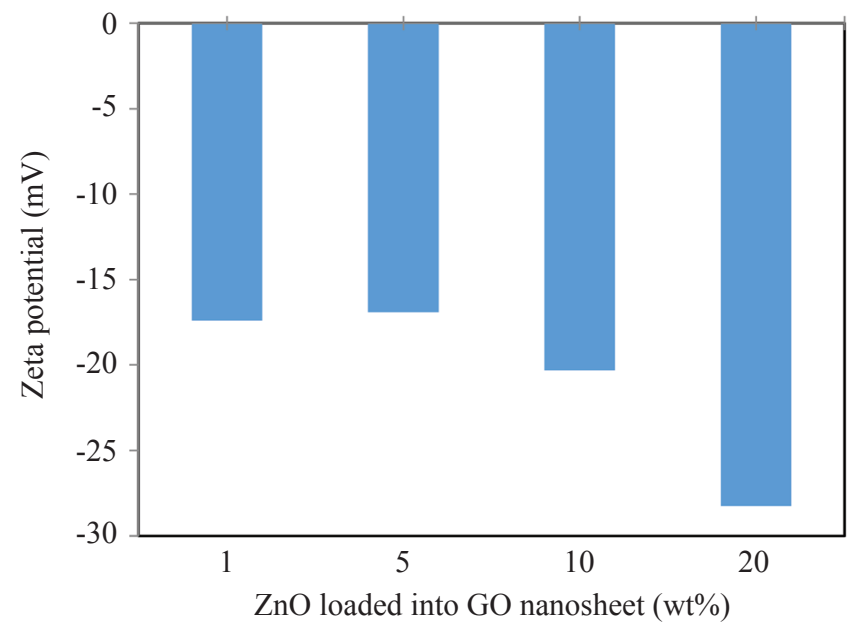

FIGURE 4. Zeta potential of $\mathrm{ZnO}$-decorated GO nanocomposite material at different weight percent of $\mathrm{ZnO}$

\section{CONCLUSION}

In this study, $\mathrm{ZnO}$-decorated GO nanocomposite material was successfully synthesized via sol-gel method. The inclusion effect of difference weight percent of $\mathrm{ZnO}$ loading in $\mathrm{ZnO}$-decorated GO nanocomposite material on crystallite phase, hydrodynamic particle size, and zeta potential were also investigated. Besides, the morphological and structure properties of $\mathrm{ZnO}$-decorated $\mathrm{GO}$ nanocomposite material were investigated. It was found that the $\mathrm{ZnO}$-decorated $\mathrm{GO}$ nanocomposite material was composed of spherical-like $\mathrm{ZnO}$ NPs anchored on GO sheet. The XRD patterns of $\mathrm{ZnO}$ decorated GO nanocomposite material indicate the formation of wurtzite $\mathrm{ZnO}$ NPs. The increasing weight percent of $\mathrm{ZnO}$ loading results in increasing hydrodynamic particle size, which the range size generated approximately $28 \mathrm{~nm}$ to $57 \mathrm{~nm}$, and negatively zeta potential value from $-16.90 \mathrm{mV}$ to -28.23 $\mathrm{mV}$. Therefore, the results demonstrated a stable suspension of $\mathrm{ZnO}$-decorated GO nanocomposite material and thus these features make the $\mathrm{ZnO}$-decorated GO nanocomposite material an excellent candidate for various applications relating to the enhancing process efficiency.

\section{ACKNOWLEDGEMENT}

The authors appreciate the financial support by Indah Water Konsortium Sdn. Bhd. (KK-2018-005) and Geran Universiti Penyelidikan (GUP-2017-098). In addition, the authors also wish to acknowledge the Ministry of Education Malaysia for 
sponsoring the postgraduate study of Nurul 'Adilah Rosnan through the MyBrain program. The Centre for Research and Instrumentation Management (CRIM) UKM is also acknowledged for XRD and FESEM analysis.

\section{REFERENCES}

Ahmed, M.I., Hussain, Z., Mujahid, M., Khan, A.N., Javaid, S.S. \& Habib, A. 2016. Low resistivity ZnO-GO electron transport layer based $\mathrm{CH}_{3} \mathrm{NH}_{3} \mathrm{PbI}_{3}$ solar cells. AIP Advances 6: 1-12.

Amat, N.F., Andanastuti, M.,Mariyam, J.G. \& Nurziha, Y. 2012. Kesan agen penyerak dan $\mathrm{pH}$ ampaian dalam pemprosesan serbuk nano zirconia. Jurnal Kejuruteraan 24: $15-20$.

Anitha, S.N. \& Jayakumari, I. 2015. Synthesis and analysis of nanocrystalline $\mathrm{e} \mathrm{Fe}_{2} \mathrm{Mn}_{2} \mathrm{Ni}_{0.5} \mathrm{Zn}_{1.5} \mathrm{O}_{9}$ at different treating temperatures. Journal of Nanoscience and Technology 1: 26-31.

Bao, Q., Zhang, D. \& Qi, P. 2011. Synthesis and characterization of silver nanoparticle and graphene oxide nanosheet composites as a bactericidal agent for water disinfection. Journal of Colloid and Interface Science 360: $463-$ 470.

Benhebal, H., Chaib, M., Salmon, T., Lambert, D., Crine, M. \& Heinrichs, B. 2013. Photocatalytic degradation of phenol and benzoic acid using zinc oxide powders prepared by the sol - gel process. Alexandria Engineering Journal 52: 517-523.

Bodson, C.J., Lambert, S.D., Alié, C., Cattoën, X., Pirard, J.P., Bied, C. \& Man, M.W.C. 2010. Effects of additives and solvents on the gel formation rate and on the texture of P- and Si-doped $\mathrm{TiO}_{2}$ materials. Microporous and Mesoporous Materials 134: 157-164.

Chao, X., Wu, X., Zhu, J. \& Wang, X. 2008. Synthesis of amphiphilic graphite oxide. Carbon 46: 386-389.

Chen, Y.L., Zhang, C.E., Deng, C., Fei, P., Zhong, M. \& $\mathrm{Su}$, B.T. 2013. Preparation of $\mathrm{ZnO} / \mathrm{GO}$ composite material with highly photocatalytic performance via an improved two-step method. Chinese Chemical Letters 24: 518-520.

Chu, D. \& Li, S. 2012. Growth and electrical properties of doped $\mathrm{ZnO}$ by electrochemical deposition. Journal of Glass and Ceramics 2: 13-16.

Chung, Y.T., Mahmoudi, E., Mohammad, A.W., Benamor, A., Johnson, D. \& Hilal, N. 2017. Development of polysulfone-nanohybrid membranes using $\mathrm{ZnO}-\mathrm{GO}$ composite for enhanced antifouling and antibacterial control. Desalination 402: 123-132.

Duffy, G., Pillai, S.C. \& McCormack, D.E. 2007. The effect of the rate of precursor production on the purity and aggregation morphology of nanoparticulate zinc oxide. Journal of Materials Chemistry 17: 181-184.

Fan, Z. \& Lu, J.G. 2005. Zinc oxide nanostructures: synthesis and properties. Journal of Nanoscience and Nanotechnology 5(10): 1561-1573.
Gayathri, S., Jayabal, P., Kottaisamy, M. \& Ramakrishnan, V. 2014. Synthesis of $\mathrm{ZnO}$ decorated graphene nanocomposite for enhanced photocatalytic properties. Journal of Applied Physics 115: 1-9.

Hasnidawani, J.N., Azlina, H.N., Norita, H., Bonnia, N.N., Ratim, S. \& Ali, E.S. 2016. Synthesis of ZnO nanostructures using sol-gel method. Procedia Chemistry 19: 211-216.

Ho, K.C., Teow, Y.H., Ang, W.L. \& Mohammad, A.W. 2017. Novel GO,OMWCNTs mixed-matrix membrane with enhanced antifouling property for palm oil mill effluent treatment. Separation and Purification Technology 177: 337-349.

Hummers JR, W.S. \& Offeman, R.E. 1958. Preparation of Graphitic Oxide. Journal of the American Chemical Society 80: 1339-1339.

Lambert, S., Sacco, L., Ferauche, F., Heinrichs, B., Noels, A. \& Pirard, J.-P. 2004. Synthesis of $\mathrm{SiO}_{2}$ xerogels and $\mathrm{Pd} / \mathrm{SiO}_{2}$ cogelled xerogel catalysts from silylated acetylacetonate ligand. Journal of Non-Crystalline Solids 343: 109-120.

Li, B., Cao, H., Yin, J., Wu, Y.A. \& Warner, J.H. 2012. Synthesis and separation of dyes via Ni@reduced graphene oxide nanostructures. Journal of Materials Chemistry 22: 1876-1883.

Liang, S., Xiao, K., Mo, Y. \& Huang, X. 2012. A novel ZnO nanoparticle blended polyvinylidene fluoride membrane for anti-irreversible fouling. Journal of Membrane Science 394-395: 184-192.

Luković Golić, D., Branković, G., Počuča Nešić, M., Vojisavljević, K., Rečnik, A., Daneu, N. \& Bernik, S. 2011. Structural characterization of self-assembled $\mathrm{ZnO}$ nanoparticles obtained by the sol-gel method from $\mathrm{Zn}\left(\mathrm{CH}_{3} \mathrm{COO}\right)_{2} \cdot 2 \mathrm{H}_{2} \mathrm{O}$. Nanotechnology 22: 1-9.

Mandzy, N., Grulke, E. \& Druffel, T. 2005. Breakage of $\mathrm{TiO}_{2}$ agglomerates in electrostatically stabilized aqueous dispersions. Power Technology 160: 121-126.

Ng, L.Y., Mohammad, A.W., Leo, C.P. \& Hilal, N. 2013. Polymeric membranes incorporated with metal/ metal oxide nanoparticles: A comprehensive review. Desalination 308: 15-33.

Paredes, J.I., Rodil-Villar, S., Martinez-Alonso, A. \& Tascon, J.M.D. 2008. Graphene oxide dispersions in organic solvents graphene oxide dispersions in organic solvents. Langmuir 24: 10560-10564.

Qin, J., Zhang, X., Xue, Y., Kittiwattanothai, N., Kongsittikul, P., Rodthongkum, N. \& Limpanart, S. 2014. A facile synthesis of nanorods of $\mathrm{ZnO} /$ graphene oxide composites with enhanced photocatalytic activity. Applied Surface Science 321: 226-232.

Shen, L., Bian, X., Lu, X., Shi, L., Liu, Z., Chen, L. \& Hou, Z. 2012. Preparation and characterization of $\mathrm{ZnO} /$ polyethersulfone (PES) hybrid membranes. Desalination 293: 21-29.

Stypuła, B., Kmita, A. \& Hajos, M. 2014. Morphology and structure of Zno nanoparticles produced by electrochemical method. Materials Science 20: 3-9. 
Tavakoli, A., Sohrabi, M. \& Kargari, A. 2007. A review of methods for synthesis of nanostructured metals with emphasis on iron compounds. Chemical Papers 61: 151-170.

Van Werde, K., Mondelaers, D., Vanhoyland, G., Nelis, D., Van Bael, M. K., Mullens, J. \& Van Poucke, L. C. 2002. Thermal decomposition of the ammonium zinc acetate citrate precursor for aqueous chemical solution deposition of ZnO. Journal of Materials Science 37: 81-88.

Vaseem, M., Umar, A. \& Hahn, Y. B. 2010. ZnO nanoparticles: growth, properties, and applications. Metal oxide nanostructures and their applications. Volume 5: American Scientific Publishers.

Wang, Y.-D., Ma, C. L., Sun, X.-D. \& Li, H.D. 2002. Preparation of nanocrystalline metal oxide powders with the surfactant-mediated method. Inorganic Chemistry Communications 5: 751-755.

Wang, Y.W., Cao, A., Jiang, Y., Zhang, X., Liu, J.H., Liu, Y. \& Wang, H. 2014. Superior antibacterial activity of zinc oxide/graphene oxide composites originating from high zinc concentration localized around bacteria. ACS Applied Materials and Interfacesaterials \& Interfaces 6: 2791-2798.

Williams, G. \& Kamat, P.V. 2009. Graphene-semiconductor nanocomposites: excited-state interactions between $\mathrm{ZnO}$ nanoparticles and graphene oxide. Langmuir 25: 13869-13873.

Xu, L. L., Bian, S. W. \& Song, K. L. 2014. Graphene sheets decorated with $\mathrm{ZnO}$ nanoparticles as anode materials for lithium ion batteries. Journal of Materials Science 49: 6217-6224.

Zhang, J., Xu, Z., Shan, M., Zhou, B., Li, Y., Li, B. \& Niu, J. 2013. Synergetic effects of oxidized carbon nanotubes and graphene oxide on fouling control and anti-fouling mechanism of polyvinylidene fluoride ultrafiltration membranes. Journal of Membrane Science 448: 8192.
Zhang, Y.L., Yang, Y., Zhao, J.H., Tan, R.Q., Cui, P. \& Song, W.J. 2009. Preparation of $\mathrm{ZnO}$ nanoparticles by a surfactant-assisted complex sol-gel method using zinc nitrate. Journal of Sol-Gel Science and Technology 51: 198-203.

Zhao, S., Yan, W., Shi, M., Wang, Z., Wang, J. \& Wang, S. 2015. Improving permeability and antifouling performance of polyethersulfone ultrafiltration membrane by incorporation of $\mathrm{ZnO}-\mathrm{DMF}$ dispersion containing nano- $\mathrm{ZnO}$ and polyvinylpyrrolidone. Journal of Membrane Science 478: 105-116.

*Teow Yeit Haan

Chemical Engineering Program,

Research Centre for Sustainable Process Technology (CESPRO)

Faculty of Engineering \& Built Environment

Universiti Kebangsaan Malaysia, Bangi, Malaysia.

Nurul 'Adilah Rosnan

Chemical Engineering Program

Faculty of Engineering \& Built Environment

Universiti Kebangsaan Malaysia, Bangi, Malaysia.

Abdul Wahab Mohammad

Qatar Energy and Environment Research Institute (QEERI)

Hamad bin Khalifa University (HBKU)

Qatar Foundation, Doha, Qatar.

*Corresponding author; email: yh_teow@ukm.edu.my

Received date: $5^{\text {th }}$ January 2018

Accepted date: $4^{\text {th }}$ August 2018

Online first date: $1^{\text {st }}$ September 2018

Published date: $31^{\text {st }}$ October 2018 